\title{
A Case Study of Fire and Evacuation in a Multi-Purpose Office Building, Osaka, Japan
}

\author{
S. HORIUCHI
}

Department of Architecture

Kansai University, Suita, Japan

\section{Y. MUROZAKI}

Department of Environmental Planning

Kobe University, Kobe, Japan

\section{A. HOKUGO}

Fire Information and Research Center

Mitaka, Japan

\section{ABSTRACT}

On April 4, 1984 a fire occurred at the Science and Technology Center of osaka. The building was a typical multi-purpose office building which contained the office of various learned societies whose occupants were regular users of the building, and assembly halls used by people less familiar with the premises. The purpose of this study is to form a basis for future guidlines for the evacuation of multi-purpose buildings, a building type which has become increasingly common in recent years. Oux research group conducted a survey of people who were in the center at the time of the fire using a questionnaire, and obtained detailed information about the fire and the various actions the evacuees took. On the basis of our survey we sought to analyse the characteristics of the evacuees, their reactions to spatial conditions during the evacuation, and how they experienced the sequence of events throughout the emergency. An important result of our analysis that emexged very aramatically was the difference between regular users of the building and those less familiar with it. The differences were; action upon becoming aware of the fire, criterion for selecting escape routes, and ability to effectively reach an exit.

TABLE 1. Floor by floor breakdown of the Building and the occupants.

\begin{tabular}{|c|c|c|c|c|c|c|c|c|c|c|c|}
\hline \multirow{2}{*}{$\frac{f 100}{8}$} & \multirow{2}{*}{$\begin{array}{c}\begin{array}{c}\text { Eloor } \\
\text { area } \\
\left(\mathrm{m}^{2}\right)\end{array} \\
1,177\end{array}$} & \multicolumn{2}{|c|}{$\begin{array}{l}\text { area } \\
\text { burned } \\
\left(\mathrm{m}^{2}\right)\end{array}$} & \multirow{2}{*}{$\begin{array}{l}\text { main } \\
\text { use } \\
\text { embly he }\end{array}$} & \multicolumn{2}{|c|}{$\begin{array}{l}\text { number } \\
\text { of } \\
\text { occupants }\end{array}$} & \multirow{2}{*}{$\begin{array}{l}\begin{array}{l}\text { number } \\
\text { of } \\
\text { evacuees }\end{array} \\
70\end{array}$} & \multicolumn{2}{|c|}{$\begin{array}{l}\text { number of } \\
\text { rescued } \\
\text { by window }\end{array}$} & $\begin{array}{l}\text { method } \\
\text { of } \\
\text { rescue }\end{array}$ & $\begin{array}{l}\text { number of } \\
\text { questionnaires } \\
\text { collected }(\%)\end{array}$ \\
\hline & & - & ass & & $11 \mathrm{~s}$ & 70 & & - & - & & $61(87.1)$ \\
\hline 71 & 1,177 & - & res & taurant & offices & 594 & 94 & - & - & & $67(71.3)$ \\
\hline 6 & 1,177 & - & off & ices, a. & alls & 85 & 83 & 2 & & adder truck & $51(60.0)$ \\
\hline 5 & 1,177 & - & off & ices & & 63 & $* 61$ & 2 & & adder truck & $39(61.9)$ \\
\hline 4 & 1,177 & - & ass & embly ha & $1.1 \mathrm{~s}$ & 254 & 158 & 96 & & adder truck & $170(66.9)$ \\
\hline 3 & 1,177 & 473 & off & ices & & 50 & 48 & 2 & & ortable ladder & $38(76.0)$ \\
\hline 2 & 1,176 & - & exh & ibition & halls & 11 & 11 & - & - & & - \\
\hline 1 & 1,124 & - & exh & ibition & halls & 14 & 14 & - & - & & - \\
\hline B1 & 1,161 & - & res & taurant & & 29 & 29 & - & - & & $23(79.3)$ \\
\hline B2 & 1,150 & - & mec & hanical & rooms & 9 & 9 & - & - & & $7(77.8)$ \\
\hline EV & - & - & - & & & - & - & - & - & & 2 \\
\hline & 2,485 & 473 & 120 & tal) & & 679 & 577 & 1.02 & - & & $458(67.5)$ \\
\hline
\end{tabular}




\section{METHOD}

Our research group began our investigation two weeks after the fire. We wrote a 23 item questionnaire and the Fire Defense Board of osaka distributed it to the 679 individuals who were in the science and Technology center at the time of the fire. Of the questionnaires distributed, 458 were returned to the Fire Defense Boad (see TABLE 1.). Each step of the evacuation was analyzed and delineated.

\section{ANATYSIS}

The Fire, the Building, and the Occupants

Time. April 4, 1984, appoximately 11:25 am.

Place. Osaka, West District, Science and Technology Center of osaka, 3rd floor, a hallway near the west stairs.

The burned area. $473 \mathrm{~m}^{2}$ of the floor and $62 \mathrm{~m}^{2}$ of the cieling surface on the $3 \mathrm{rd}$ floor, $88 \mathrm{~m}^{2}$ of the exterior wall surface on the 4 th floor.

Injured. 8 persons. All sustained carbon monoxide poisoning, all alive.

Cause. Arson suspected.

The building. A reinforced concrete structure 8 stories high. Essential facilities (elevators, main stairs, lavatories etc.) located in the center core. In addition to central stairs, enclosed stairs on the east and west ends of the building. These enclosed stairs are protected by fire doors which are kept closed.

Occupants. The regular users of the building occupied offices on the $3 r d$ and 5th floors. The assembly halis on the 4th and 6 th floors were being used for new employee training sessions, and the occupants were not familiar with the building. The occupants of the 7 th and 8 th floor were attending conferences and were not regulax users of the building although most had been in the builaing before (see FIGURE 1.).

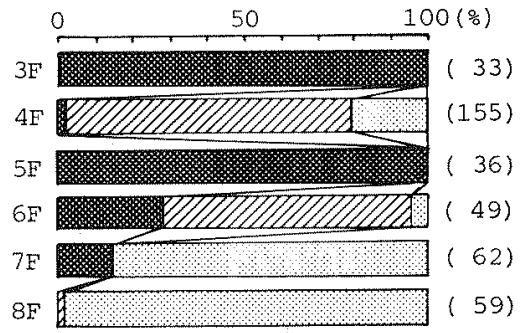

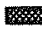

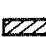

28 every day those who came to the building to attend conferances or seminars for the first time

1 those who came to the building to attena conferances or seminars, but had been in the building before

एother

FIGURE 1. Characteristics of the occupants 


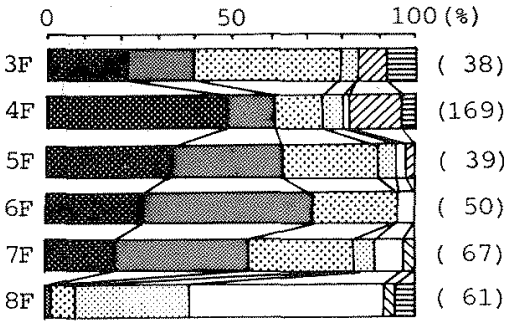

heavey, dense smoke

poor visibility

some visibility

0 little smoke

$\longrightarrow$ no smoke

שa those who aidn't venture into the corridor and thus couldn't answer

DS those who evacuated immediately and didn't notice

$\Longrightarrow$ other

FIGURE 2. The amount of smoke in the corridor when evacuees became aware of the fire

The Fire and the spread of smoke

Discovery of fire. An employee of the Centex working on the $3 r d$ floor heard an explosive sound and rushed to investigate. The employee found the floor of hallway near the west stairway in flames, and the ceiling engulfed in smoke. An employee in charge of fire prevention who was working on the same floor told another employee to get a fire extinguisher and try to use it. He then ran to the 1st floor security office and told the security officer to inform the fire department. At the same time he alerted all of the floors over the public address system. The contents of the announcement he repeated was, "Do not use the Central stairway. Plese evacuate via the east or west emergency stairways." The fire department records his call at approximately $11: 32$ in the morning.

The arrival of the fire department. At 11:39 the first group of fire fighters arrived and black smoke was pouring from a window on the south side of the 3 rd floor. There were several hundred evacuees already in the streets surrounding the building. Many occupants unable to evacuate coula be seen waving from windows between the $3 r d$ and 6 th floors.

The spread of smoke. Because the fire shutters for the central stairway were not closed, smoke spread to the floors above. FIGURE 2. shows the spread of smoke to the various flooxs at the time when the occupants became aware of the fire. The results of our questionnaire show that occupants of the $3 r d$ floor did not see heavy smoke. This can probably attibuted to the relatively early discovery of fire by the occupants of the 3rd floor.

\section{Awareness of the Fire}

In our questionnaire we asked, "How did you become aware of the fire ?", and gave a series of multiple choice answers, letting the participants choose as many answers as they felt were appropriate. We also asked, "What made you believe it was a real fire ?", but asked them to chose only one answer from the list available. The answers to these questions are compiled on a floor by floor basis in FIGURE 3 . 


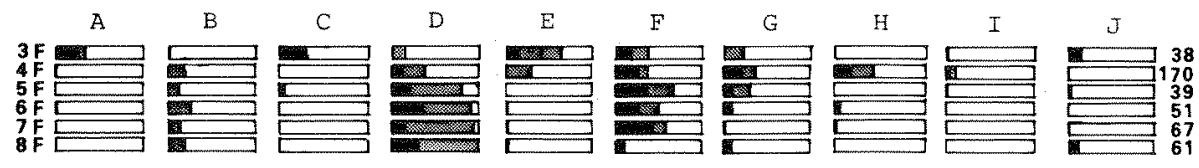

\author{
A: seeing the fire \\ $B$ : smelling \\ C:hearing explosive sounds \\ D:hearing the announcement over the public adress system \\ E:hearing others yelling \\ F:opening their door and finding smoke in the corridors \\ G: smoke entering the room \\ H:being alerted by seminar leaders \\ I:being alerted by others (other than seminar leaders) \\ J:other
}

those realizing the fire to be real in the above way

those who answered that the above was a secondary reason for believeing the fire to be real

$\square$ did not $f$ ind the above to be the reason for believeing the fire to be real

FIGURE 3. Analysys of how occupants became aware of the fire

31.6\% of the occupants of the $3 \mathrm{rd}$ floor, where the fire broke out, reported hearing an explosive sound and wondering what it was. $52.6 \%$ of the occupants reported hearing others trying to extinguish the fire and knew something was wrong. $13.2 \%$ of the occupants heard noises and knew immediately it was a fire. $31.6 \%$ acutually saw the fire and thus grasped the reality of the emergency.

Occupants on the upper floors (4-8) heard the announcement of the fire, opened their doors, and found the hallways filled with smoke. Most grasped the reality of the emergency in this way. Bcause of proximity to the source of the fire, smoke spread to the 4th floor faster than to the other floors. Training sessions were in progress and the doors to most of the rooms were closed, so most trainees did not become aware of the fire untill their leaders alerted them. By this time, smoke was thick in the hallways. Occupants of room 404, which exited into an area adjacent to the central stairway, found smoke so thick that their leaders told them not to exit.

When occupants of the 8 th floor became aware of the fire relatively little smoke had spread into the coxridors. Most of the occupants on the 8th floor became aware of the fire by the public address.

\title{
Actions Taken
}

FIGURE 4. shows the various courses of action taken by the occupants. Five patterns emerged:

a) those who thought to extinguish the fire before evacuating

b) those who thought to set the fire alarm and/or evacuate others before 


\begin{tabular}{|c|c|}
\hline $\begin{array}{l}\text { occupants who thought } \\
\text { only to evacuated }\end{array}$ & $\begin{array}{l}\text { evacuated (18 pexsons) } \\
\text { evacuated- returned- }\end{array}$ \\
\hline $\begin{array}{l}\text { occupants who } \\
\text { experienced confusion } \\
\text { and disorientation } \\
\text { and then thought } \\
\text { to evacuate }\end{array}$ & 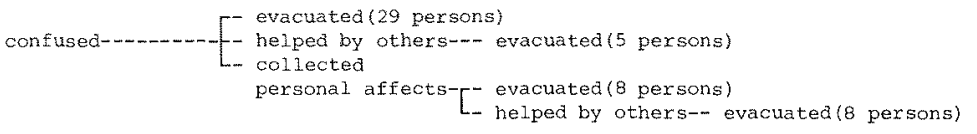 \\
\hline $\begin{array}{l}\text { occupants who thought } \\
\text { to set the Eire aiarm } \\
\text { and/or help others } \\
\text { and then evacuated }\end{array}$ & 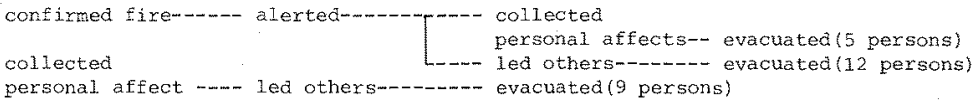 \\
\hline $\begin{array}{l}\text { occupants who thought } \\
\text { to extinguish } \\
\text { the fire, and then } \\
\text { evacuated }\end{array}$ & 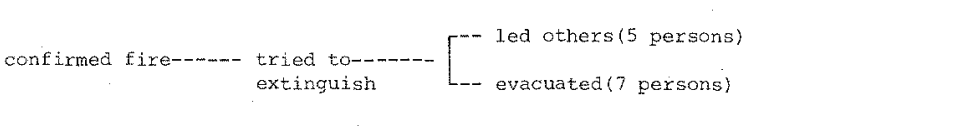 \\
\hline $\begin{array}{l}\text { occupants who chose to } \\
\text { wait for fire fightexs } \\
\text { to rescue them }\end{array}$ & 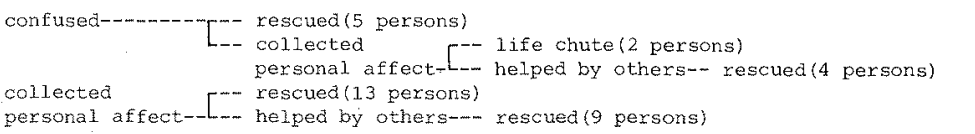 \\
\hline
\end{tabular}

Explanatory notes

confused=An unstable psychological condition. Experienced confusion and disorientation

confirmed $f$ ite=Tried to find the source of the fire or went into the hallway to confirm the fire

tried to extinguish=tried to extinguish the fire with a fire extinguisher

alerted=tried to set an alarm or alert fire officials

collected personal affectsmspent some time arranging personal. work area or collecting personal affects led otherswent into the corricor and led others to the stairs

evacuated=went into the hall and attempt to evacuate

returned=went into the corridor but returned to the room because of heavy smoke

rescued =rescued by hook and rudder truck

life chute=evacuated via lize chute

helped by othersthose who recieved aid from others

FIGURE.4. Major pattems of evacuation

evacuating.

c) those who thought only to evacuate

d) those who experiensed confusion and disorientation and then thought to evacuate

e) those who chose to wait for fire fighters to rescue them. 


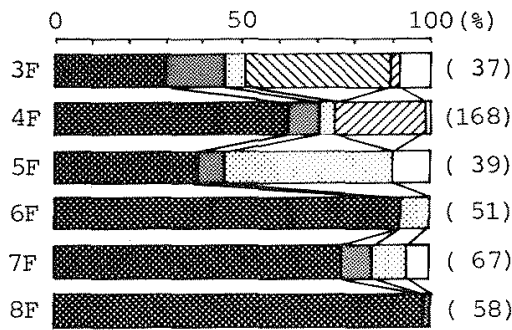

occupants who thought only to evacuate

occupants who experienced confusion and disorientation and then thought to evacuate

0 occupants who thought to set the fire alarm and/or help others and then evacuate occupants who thought to extinguish the fire, and then evacuate

[Z2 occupants who chose to wait for fire fighters to rescue them other

FIGURE 5. Floor by floor breakdown of evacuation patterns

The distribution of occupants from these five groups and the floors they occupied is shown in EIGURE 5. Those who thought to extinguish the fire(a) were all occupants of the 3rd floor. Those who sought to alert or help others(b) were largely from the 4th floor. Those who thought only to evacuate (c) were from floors $4,6,7$ and 8 . That occupants of the $3 r d$ and 5 th floors were regular of the building and had their own offices probably accounts for the large proportion of them who thought extinguish the fire or alert and help others (see FIGURE 1.).

On other floors where attendants of training sessions were largely unfamiliar with the building, the thought of direct evacuation was predominant.

\section{Selection of Evacuation Routes}

FIGURE 6. shows the responses to the following question : "How did you decide whether to evacuate through the hallway or whether to stay where you were ?" occupants on the highest floors were found to have evacuated quite qujckly. It can be assumed that the absense of dense smoke on the highest floors (see FIGURE 2.) made it possible for occupants to quickly make the decision to

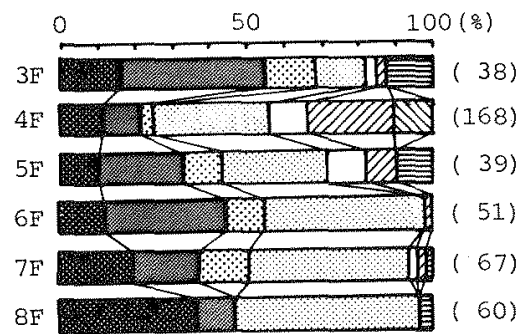

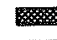

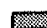

followed the instructions of others and evacuated

molded they would be able to evacuate

0 found the choice difficult but decided to evacuate

$\square$ wanted to evacuate but stayed where they were

EZa decided it woula be safest to stay where they were

$5 \mathrm{w}$ were told by others not to evacuate

othex

FIGURE 6. Selection of evacuation routes 

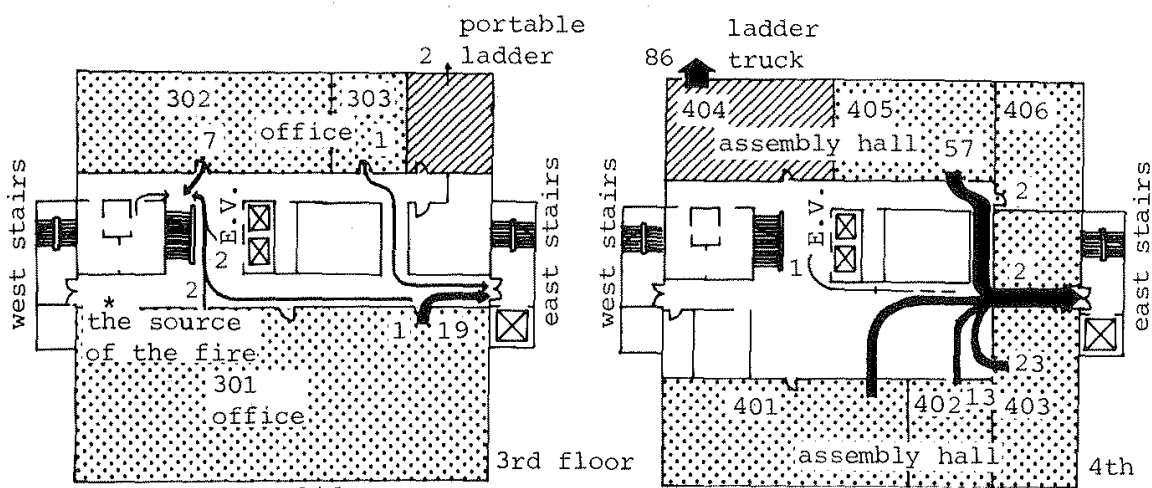

life ladder ladder
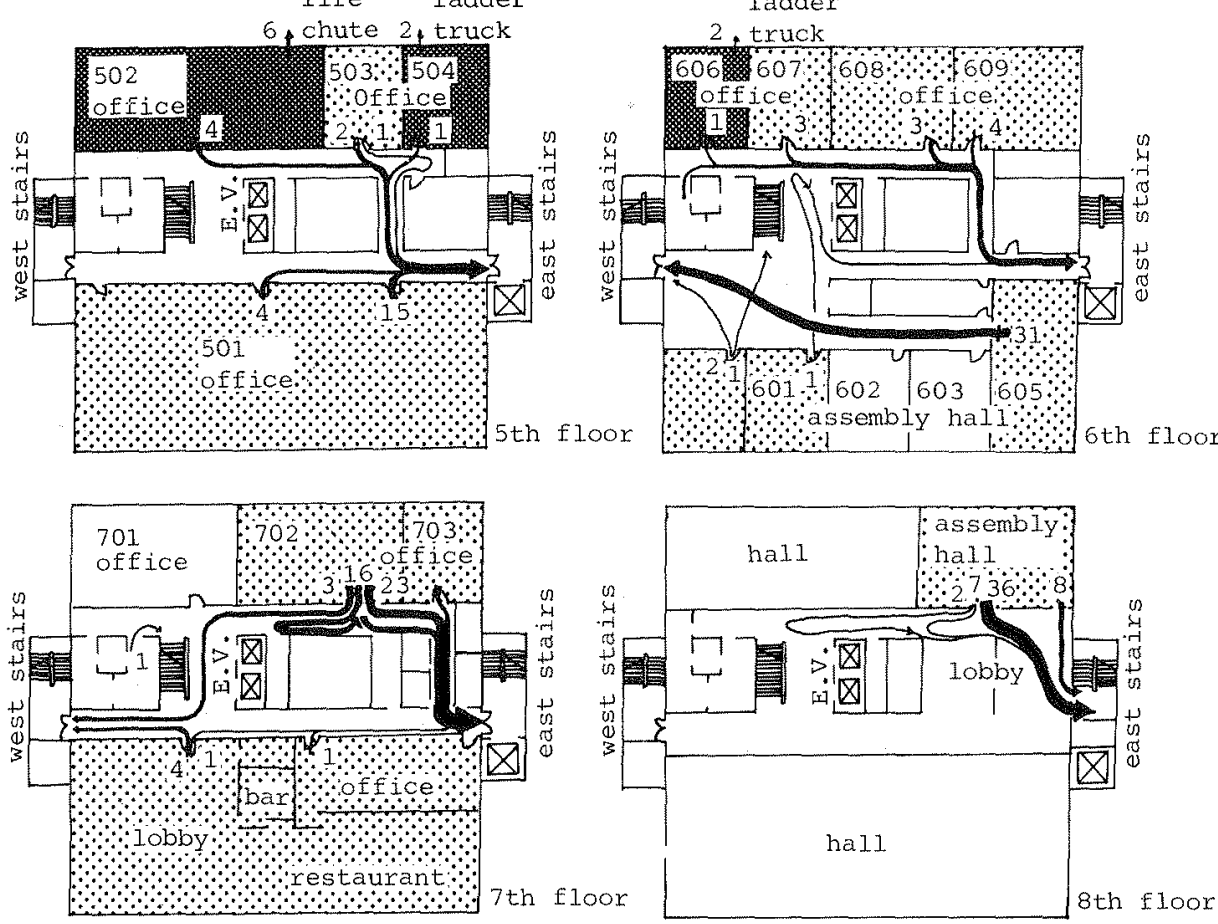

occupants of same room divided, some evacuating via the corridor, others via the window

$\because 3$ all occupants evacuated via the corridox

EZy all occupants evacuated via the window

FIGURE 7. Choice of evacuation route 
TABLE 2. Case when occupants of the same room devided, some evacuating via the window, others via the corridor

\begin{tabular}{|c|c|c|c|c|c|c|c|c|c|}
\hline \multirow[b]{2}{*}{ room } & \multicolumn{4}{|c|}{ Those who evacuated via corridor } & \multicolumn{5}{|c|}{ Those who evacuated(rescued) via window } \\
\hline & & $x$ age & $\begin{array}{l}\text { working } \\
\text { position }\end{array}$ & $\begin{array}{l}\text { reason for } \\
\text { choosing } \\
\text { evacuation route }\end{array}$ & & $x$ age & $\begin{array}{l}\text { fe working } \\
\text { position }\end{array}$ & & $\begin{array}{l}\text { iod of } \\
\text { uation } \\
\text { scue) }\end{array}$ \\
\hline 606 & $F$ & 24 & $\begin{array}{l}\text { clark, } \\
\text { regular user }\end{array}$ & knew stajixway & $M$ & 39 & $\begin{array}{l}\text { office manager, } \\
\text { not regular user }\end{array}$ & lad & ler truck \\
\hline 504 & $\mathrm{~F}$ & 44 & $\begin{array}{l}\text { clark, } \\
\text { regular user }\end{array}$ & announcement & $M$ & 80. & $\begin{array}{l}\text { managing director } \\
\text { regular user }\end{array}$ & lad & ler truck \\
\hline 502 & $\begin{array}{l}F \\
F \\
F \\
M\end{array}$ & $\begin{array}{l}30 \\
36 \\
38\end{array}$ & $\begin{array}{l}\text { clark, } \\
\text { regular user } \\
\text { clark, } \\
\text { regular user } \\
\text { clark } \\
\text { regular user } \\
\text { office manager, } \\
\text { regular user }\end{array}$ & $\begin{array}{l}\text { always used stairs } \\
\text { knew stairway } \\
\text { always used stairs } \\
\text { knew stairway } \\
\text { always used stairs }\end{array}$ & $\begin{array}{l}M \\
M \\
M \\
M \\
M \\
M \\
M\end{array}$ & 41 & $\begin{array}{l}\text { ofice manager, } \\
\text { regular user } \\
\text { office managex, } \\
\text { regular user } \\
\text { managex } \\
\text { regular user } \\
\text { fast-time employer } \\
\text { regular user } \\
\text { manager, } \\
\text { regular user } \\
\text { driver, } \\
\text { regular user } \\
\text { acting branch mana } \\
\text { regular user }\end{array}$ & 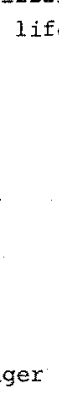 & $\begin{array}{l}\text { cute } \\
" \\
"\end{array}$ \\
\hline
\end{tabular}

exit, and then to traverse the corridors into the emergency stairwells with little trouble. The upper floors also had a higher proportion of occupants to be instructed by others to evacuate. On floors 3,5 and 6 where occupants were largely regular users of the building, those who chose to exit via the hallway were the majority instead of dense smoke.

In contrast, many occupants on the 4th and 5 th floors decided not venture into the hallways or decided it was safe to stay where they were. The smoke was very dense on these flooxs by the time occupants became aware of the fire, and it can be concluded that the amount of smoke directly contributed to their choice to stay where they were.

FIGURE 7. Shows the results to the question, "Did you evacuate via the hallway or did you evacuate via the window, using the hook and ladder truck or the life chute ?" occupants of the same rooms on the 5 th and 6 th floors were divided into both groups. Besides the amount of smoke, other factors were found to play a role in how the occupants chose to evacuate. TABLE 2. shows details of these occupants. Most of those who evacuated via the hallway were women employees who were familiar with the building.

That they knew the location of the emergency stairs or often used them can be cited as a significant reason for their choice. Those who elected not to evacuate were all men employed in managerial positions. Occupants of room 606 were largely unfamiliar with the building and those in room 504 were elderly men.

It can be said that sex, job and familiarity with the building axe among the factors that contribute to the choice of evacuation route. 
those who work in the building (mainly 3 rd and 5 th floor, 102 persons)

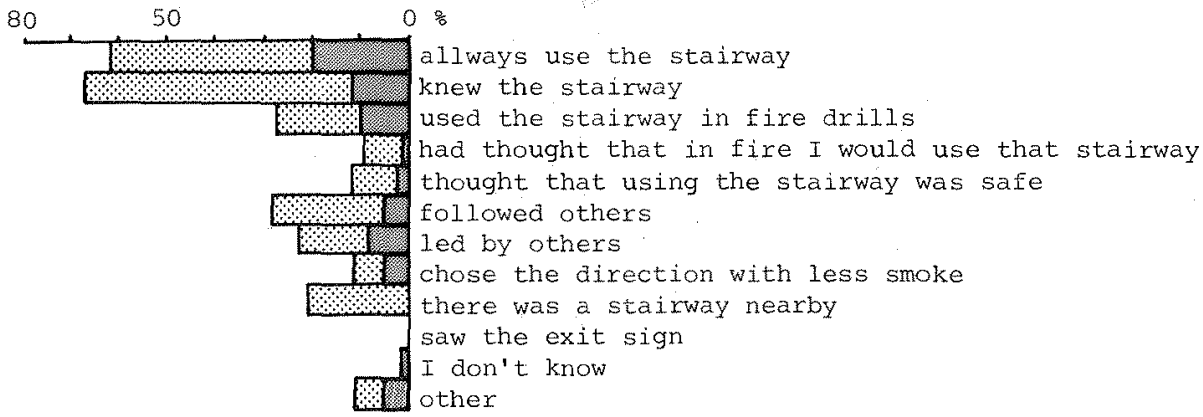

those who visited the building to attend a conference or employee's trainning for the first time (mainly 4 th and 6 th floor, 84 persons)

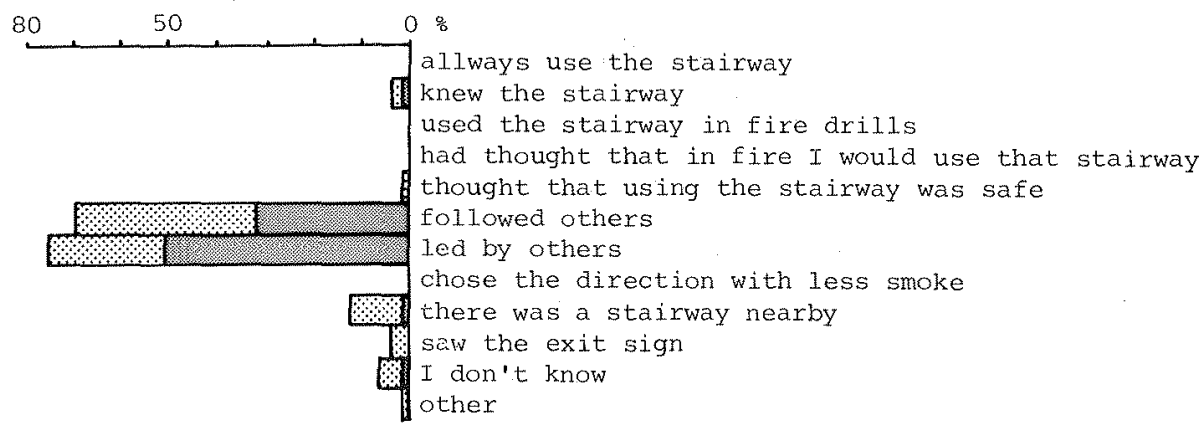

those who visit the building to attend conferences or employee's trainning, have used the building (140 persons)

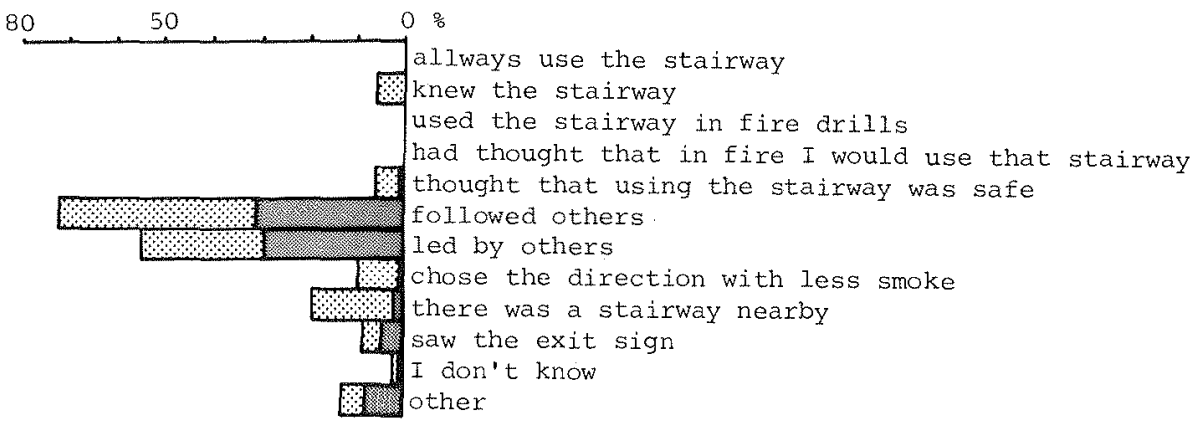

FIGURE 8. Reasons for choice of the evacuation route 
FIGURE 7. shows the plans of floors above the 3rd floor. Generaliy, the occupants on these floors evacuated via the east emergency stairway. on the 6 th floor, occupants of room 605 found that the poor visibility due to smoke made it difficult to navigate any but a straight corridor, and chose the west emergency stairway.

FIGURE 8. shows the relationship between the evacuee's familiarity with the building and their choice of evacuation route. The evacuation route is most likely chosen on the basis of amount of smoke in the corridor, but as on floor 3 and 5, regular users used staires theywer familliar with.

In contrast, occupants of floors $4,6,7$ and 8 were less familiar with the building and allowed others to guide or instruct them as to their evacuation route. Many simple followed other evacuees to the emergency stairs. These cases illustrate decision making based on the instructions or guidance of others.

\section{CONCLUSTON}

The results of this study are summarized below:

a) Regular users of the building will act in various ways that include trying to extinguish the fire, alterting others, or helping others to evacuate. In the case of those who are less familiar with the building, immediate evacuation is the normal pattern.

b) The choice of evacuation route depends mostly on the amount of smoke, but sex, job and familiarity with the building are important factores.

c) The choice of evacuation route will often be a regularly used route if the evacuee is familiar with the building. For those not familiar, following or relying on others is the norm.

d) If familiar with the building, occupants have little difficulty. finding exits even in heavy smoke. If the location of the stairs is not known, finding an exit can be of great difficulty.

e) In all phases of the evacuation process, familiarity with the building was found to be the primary determinant of speed and ease of evacuation. 